\section{Зинаида Александровна СУСЛИНА}

22 июня в расцвете сил скоропостижно скончалась директор Научного центра неврологии, академик РАН, лауреат премий Правительства РФ, заслуженный деятель науки Российской Федерации,главный редактор журнала «Анналы клинической и экспериментальной неврологии» Зинаида Александровна Суслина.

Ушел из жизни человек ярчайшего творческого дарования, один из лидеров российской неврологии, выдающийся организатор науки, удивительно цельная личность и по-настоящему красивая женщина. О таких людях говорят: гордость страны.

Вся научная и врачебная деятельность Зинаиды Александровны была неразрывно связана с Институтом (Центром) неврологии, в который она пришла в 1973 году по окончании с отличием 2-гоМОЛГМИ им. Н. И. Пирогова. После обучения в клинической ординатуре и аспирантуре 3. А. Суслина осталась работать в Институте в качестве младшего, а затем старшего научного сотрудника. В 1985-1988 гг. была руководителем научноконсультативного отделения, а в 1988 году возглавила созданное ею первое в стране специализированное отделение острых нарушений мозгового кровообращения с палатами интенсивной терапии.С 1991 по 2003 год - заместитель директора, а с 2003 года - директор НИИ (Научного центра) неврологии РАМН.

3. А. Суслина - создатель нового научного направления, связанного с изучением системы гемостаза и гемореологии при цереброваскулярных заболеваниях. Приоритетные исследования, выполненные ею в рамках концепции гетерогенности ишемического инсульта, неврологических аспектов артериальной гипертонии и проблем кардионеврологии, значительно расширили представления о патогенезе нарушений мозгового кровообращения. Внедрение полученных результатов о роли кардиальных нарушений в патогенезе и течении ишемического инсульта позволило

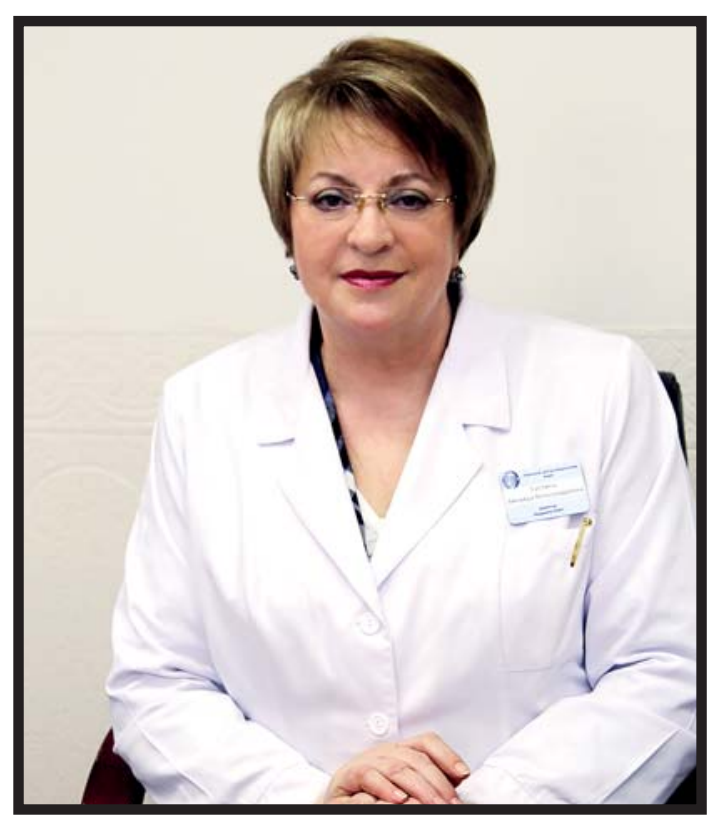

существенно улучшить непосредственный исход заболевания, а также прогноз жизни пациентов и профилактику инсульта в масштабах страны. 3. А. Суслина была признанным авторитетом в разработке научных основ клинических исследований лекарственных средств, активным участником создания ряда новых отечественных лекарственных препаратов, нашедших широкое применение в неврологической практике.

Делом всей жизни Зинаиды Александровны стало укрепление и развитие Научного центра неврологии, который она считала своим домом. Ей удалось не только достойно продолжить традиции, заложенные ее выдающимися учителями Е. В. Шмидтом и Н. В. Верещагиным, но и придать Центру новый импульс динамичного развития, объединив уникальный коллектив специалистов клинического и фундаментального профиля и создав основу для поступательного развития нейронаук в нашей стране. Велики заслуги 3. А. Суслиной в качестве академика-секретаря Отделения клинической медицины РАМН, зав. кафедрой нервных болезней стоматологического факультета МГМСУ и курса нервных болезней факультета фундаментальной медицины МГУ им. М. В. Ломоносова, председателя и активнейшего участника большого числа межведомственных комиссий и ассоциаций, занимающихся вопросами организации научных исследований в Российской Федерации.

Зинаида Александровна всегда остро чувствовала вызовы времени, искренне любила жизнь и людей, умела создать вокруг себя неповторимую атмосферу порядочности, ответственности за порученное дело, взаимного уважения.

Все, кто близко знал Зинаиду Александровну, благодарны судьбе за то, что она была в их жизни. Светлый образ Зинаиды Александровны Суслиной навсегда останется в нашей памяти и в сердцах. 